\title{
CERVIDAE FROM DHOK PATHAN AND HASNOT AREAS (DHOK PATHAN FORMATION, NORTHERN PAKISTAN) WITH COMMENTS ON THE AGE OF THESE SEDIMENTS
}

\author{
ABDUL GHAFFAR \\ Department of Meteorology, COMSATS, University Islamabad (CUI), 44000, Pakistan. \\ aghaffar@comsats.edu.pk \\ MUHAMMAD AKHTAR \\ Department of Zoology, Minhaj University, Lahore, 54000, Pakistan. \\ drakhtarfdrc@hotmail.com \\ MUHAMMAD ADEEB BABAR \\ Department of Zoology, University of the Punjab, Lahore, 54000, Pakistan. \\ babarfcc2005@yahoo.com \\ GHAZALA ROOHI \\ Earth Sciences Division, Pakistan Museum of Natural History (PMNH), Islamabad, 44000, Pakistan. \\ roohi@pmnh.gov.pk
}

\begin{abstract}
Previously described fossil remains of the family Cervidae are considered for the age estimation of two well-known fossiliferous localities of Dhok Pathan Formation (i.e. Dhok Pathan Type section and Hasnot). It is now well established that different species of the tribe Cervini appeared in the Pliocene in the Siwalik continental deposits. This information is based on the fossil record of these species, and molecular phylogenetic studies regarding the separation of different genera of the tribe Cervini also agree with this age. In previous literature, the age of these fossil sites has been recognized as late Miocene mostly, while other authors mentioned the age of these sites as Pliocene, entirely based on the mammalian fossil assemblages. Recent field surveys conducted in these localities reveals that the fossils, mostly found in pockets and fossil sites within these localities, have a late Miocene-Pliocene age, based on the mammalian fauna.
\end{abstract}

Keywords: Cervidae, lithology, Late Miocene, Pliocene, Dhok Pathan Formation.

RESUMO - Restos fósseis anteriormente descritos da família Cervidae são considerados para duas localidades fossilíferas bem conhecidas da Formação Dhok Pathan (i.e. a seção Dhok Pathan Type e Hasnot). Está bem estabelecido que diferentes espécies da tribo Cervini apareceram no Plioceno nos depósitos continentais de Siwalik. Esta informação é baseada no registro fóssil dessas espécies, e estudos filogenéticos moleculares sobre a separação de diferentes gêneros da tribo Cervini também concordam com a idade. Em trabalhos prévios, a idade dos sítios fossilíferos estudados tem sido reconhecida principalmente como Neomioceno, enquanto outros autores mencionaram como do Plioceno, inteiramente baseados nas associações de mamíferos encontrados nessas localidades. Os recentes levantamentos de campo revelam que os fósseis, encontrados principalmente em bolsões dentro dessas localidades, têm uma idade do Neomioceno-Plioceno, baseada na fauna de mamíferos.

Palavras-chave: Cervidae, litologia, Neomioceno, Plioceno, Formação Dhok Pathan.

\section{INTRODUCTION}

The available fossil record of Cervidae in the Dhok Pathan Formation has been mainly collected in the Dhok Pathan type locality, and in the area around Hasnot village. The type locality of Dhok Pathan (Lat. 33³3'32.09'N, Long. $\left.73^{\circ} 09^{\prime} 24.56^{\prime \prime} \mathrm{E}\right)$ is situated $65 \mathrm{~km} \mathrm{NE}$ from Chakwal City and is considered as extremely rich in fossils. The Hasnot village (Lat. $32^{\circ} 49^{\prime} 27.89 \mathrm{~N}$, Long. $73^{\circ} 07^{\prime} 52.68 \mathrm{E}$ ) is situated about $54 \mathrm{~km}$ west of Jhelum City in the Potwar Plateau of northern
Pakistan. These two fossil sites represent lateral facies associations within the fine-grained fossil-bearing floodplain deposits that are characteristic of a fluvial depositional environment (Barry \& Flynn, 1989; Behrensmeyer et al., 1995; Wills \& Behrensmeyer, 1995; Barry et al., 2002).

The important paleontological work conducted by different pioneer authors (Falconer \& Cautley, 1849; Lydekker, 1876, 1880, 1882, 1884, 1885, 1886; Pilgrim, 1910, 1913, 1932, 1937, 1939; Matthew, 1929; Colbert, 1935) does not address the stratigraphy of the area in detail. Similarly, 
previous authors (Sarwar, 1977; Akhtar, 1992; Bhatti, 2004; Ghaffar, 2005; Farooq, 2006; Khan, 2007, 2009) worked on the taxonomic details of different mammalian groups without mentioning the stratigraphic aspects of these fossil sites. In the last decade, Barry and colleagues conducted research and reported biostratigraphic intervals (Barry et al., 2002) from different fossil localities of the Siwaliks. This research is based on 40,000 fossils from 555 different localities, but this important work from Dhok Pathan Formation does not include the Cervidae fossil fauna, regarding that this group needs reevaluation. In addition, this report does not contain the excellent collection of fossils from these sites available at Abu-Bakr Fossil Display and Research Centre, Lahore. Similarly, Shah (2009) mentioned the age of Dhok Pathan type locality as Pliocene based on the mammalian fossil record recovered from Dhok Pathan Formation elsewhere in the Siwaliks. Therefore, the fossil sites yielding the Cervidae remains needs further study in a stratigraphic context, and the main purpose of this paper is to report the Pliocene sediments bearing the Cervidae fauna from the above mentioned fossiliferous localities (Figure 1).

Cervavitus shaanxius Zdansky, 1925 from the upper Miocene of China (Azanza et al., 2013; Wang \& Zhang, 2014), is the first representative of crown cervids with monopodial antler construction. Hitherto, no fossil record of pliocervines is reported from the Sub-continent India (Ghaffar et al., 2015). Di Stefano \& Petronio (2002) regarded C. magnus Zdansky, 1925 as the most ancient representative of Cervus during the Pliocene in Asia. Cervus elaphus Linnaeus, 1758, Cervavitus warthae Czyzewska, 1968 and Cervavitus perrieri Croizet \& Jobert, 1828 are phyletically linked with Cervavitus magnus, but $C$. elaphus is the best representative of genus Cervus in Asia. According to Pitra et al. (2004), the splitting between Axis and Rucervus is situated at the base, and further separation into Cervus, Rusa and Dama is evident in the Cervidae phylogeny based on the molecular phylogenetics. According to Croitor (2017), Cervinae members spread in Eurasia during the Pliocene, and also crossed the Himalayan Mountain and became part of faunal elements in the tropical areas of sub-continent India. Three species (Cervavitus sivalensis, Cervavitus colberti and Rusa simplicidens) apparently represent local evolution of Rucervus in the Siwaliks. According to Croitor (2014), Rucervus shares the antler-plan with Arvernoceros from the Plio-Pleistocene of western Eurasia. The known history of family Cervidae (Cervus) goes back to the first description of Lydekker (1876), when he established three species: Cervavitus simplicidens, Cervavitus triplidens, and Cervavitus latidens. Later, Lydekker (1885) transferred C. latidens from Cervus (Cervidae) to Oreas (Bovidae), and added a new species (C. sivalensis) to the faunal list. Similarly, Brown (1926) described C. punjabiensis Brown, 1926, and later Arif et al. (1991), described C. rewati from the Upper Siwaliks. Lydekker, $(1876,1880,1884)$ mentioned the beds with these species as Upper Siwaliks, while Pilgrim $(1910,1913)$ mentioned them Middle-Upper Siwaliks. In this description, Cervidae will be used to discriminate the Pliocene sediments from those of the upper Miocene, as no fossil record of the tribe Cervini is recorded before the early Pliocene (Ghaffar, 2005; Ghaffar et al., 2004, 2010, 2011, 2015). To support the early Pliocene fossil record, the lithological characteristics of these fossil sites, along with the age of these sites already mentioned in literature (Pilgrim, 1913; Colbert, 1935; Barry et al., 2002; Shah, 2009), are coupled with recent field observations to highlight the Pliocene exposures. The goal of this paper is to indicate the Pliocene sediments within the Dhok Pathan Formation at Dhok Pathan type locality and Hasnot area based on the literature review, Cervidae fossils, as well as the field observations.

\section{MATERIAL AND METHODS}

The studied specimens were collected from the sediments of the Dhok Pathan and the Hasnot (Dhok Pathan Formation), Punjab, Pakistan. The authors carried out the collections during different field trips. In addition, some of the specimens used in this study belonged earlier to the collections of the Abu-Bakr Fossil Display and Research Centre, and had been collected in the past from the above-mentioned localities (Dhok Pathan and Hasnot). According to the detailed sketch of Colbert (1935) for Dhok Pathan and Hasnot (Figures 1A-C); the localities \# 38, 43, 44, 104, 105, 138 at Dhok Pathan, and localities \# 113, 114, 115, 116, 117, 122, 140, 157, and 162 at Hasnot yielded the Cervidae fossils that represent the Pliocene sediments along with the upper Miocene ones. For this purpose, we investigated the fossil localities situated on the southern bank of Soan River in Dhok Pathan area (Figure 1B) and on the western bank of Bunnah River in Hasnot area (Figure 1C). The selection of these localities is entirely based on the Cervidae fossils in addition to other mammalian fossils stored at Abu-Bakr Fossil Display and Research Centre. Measurements of the specimens are given in millimeters ( $\mathbf{m m})$. The catalogue numbers of the specimens consist of series i.e. numerator (yearly catalogue number) and denominator (serial number of that year), i.e. 83/104 (1983/104) and 02/35 (2002/35).

Abbreviations: AMNH, American Museum of Natural History; PUPC, Punjab University Paleontological Collection; Ma, million years ago; M2, upper second molar; M3, upper third molar; p2, lower second premolar; p3, lower third premolar; $\mathbf{p 4}$, lower fourth premolar; $\mathbf{m 1}$, lower first molar; m2, lower second molar; m3, lower third molar; A, Axis; C, Cervus, $\mathbf{R}$, Rucervus.

\section{RESULTS}

Up until now, five species of the family Cervidae have been reported from the Siwalik continental deposits: Axis pujabiensis (Brown, 1926), Cervus sivalensis (Lydekker, 1880), Cervus triplidens (Lydekker, 1876), Cervus rewati (Arif et al., 1991), and Rucervus simplicidens (Lydekker, 1876) In addition, more species (i.e. Cervus colberti, Rucervus sp. I, and Rucervus sp. II) were identified and described by Azzaroli 


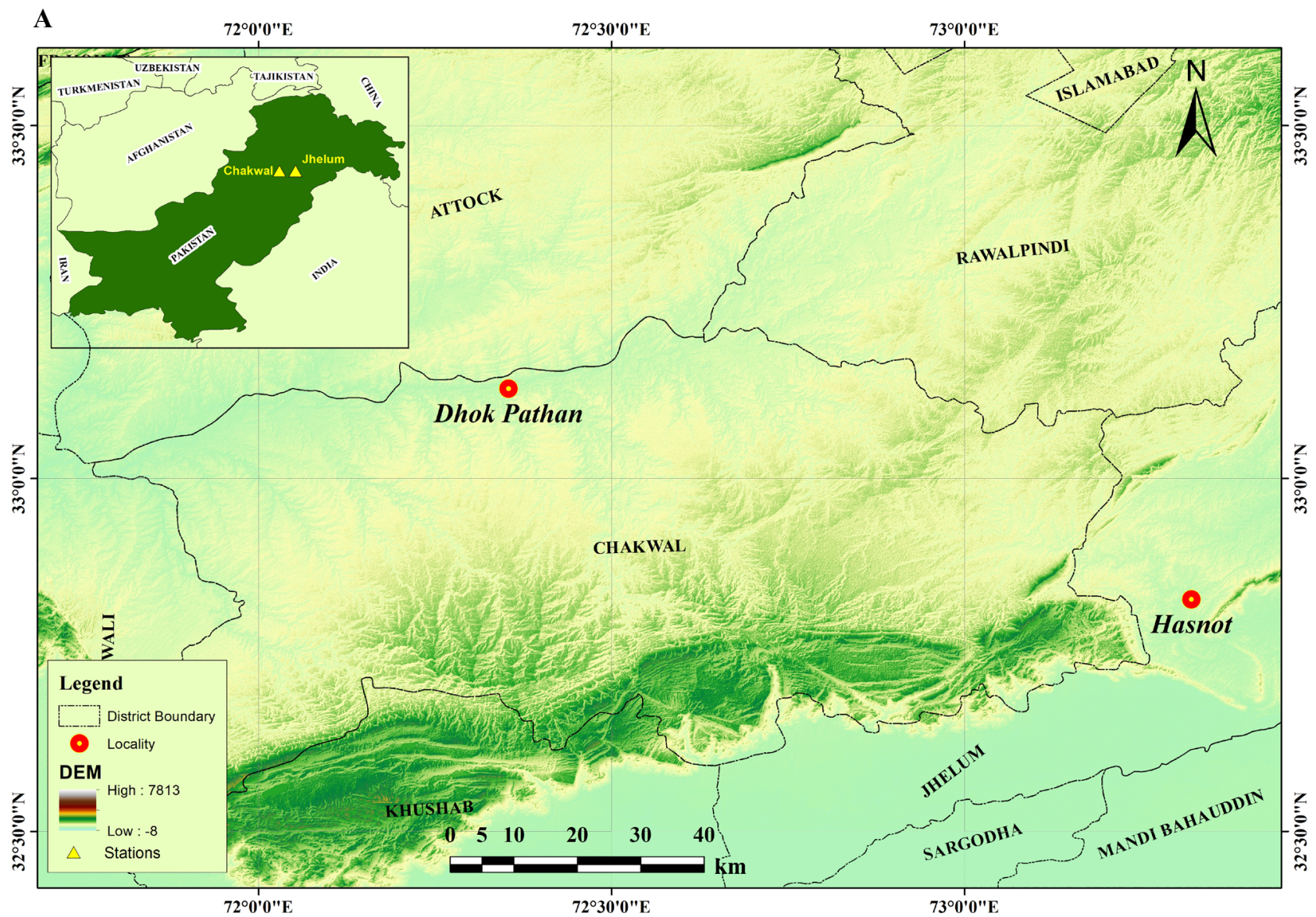

B

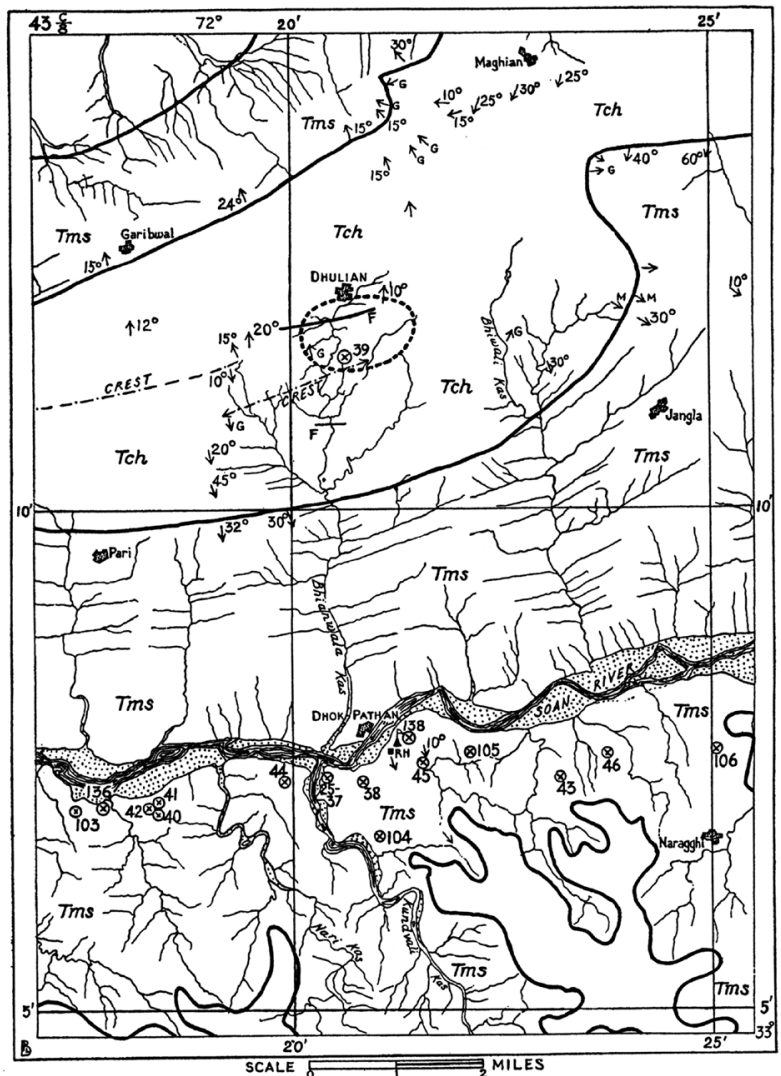

C

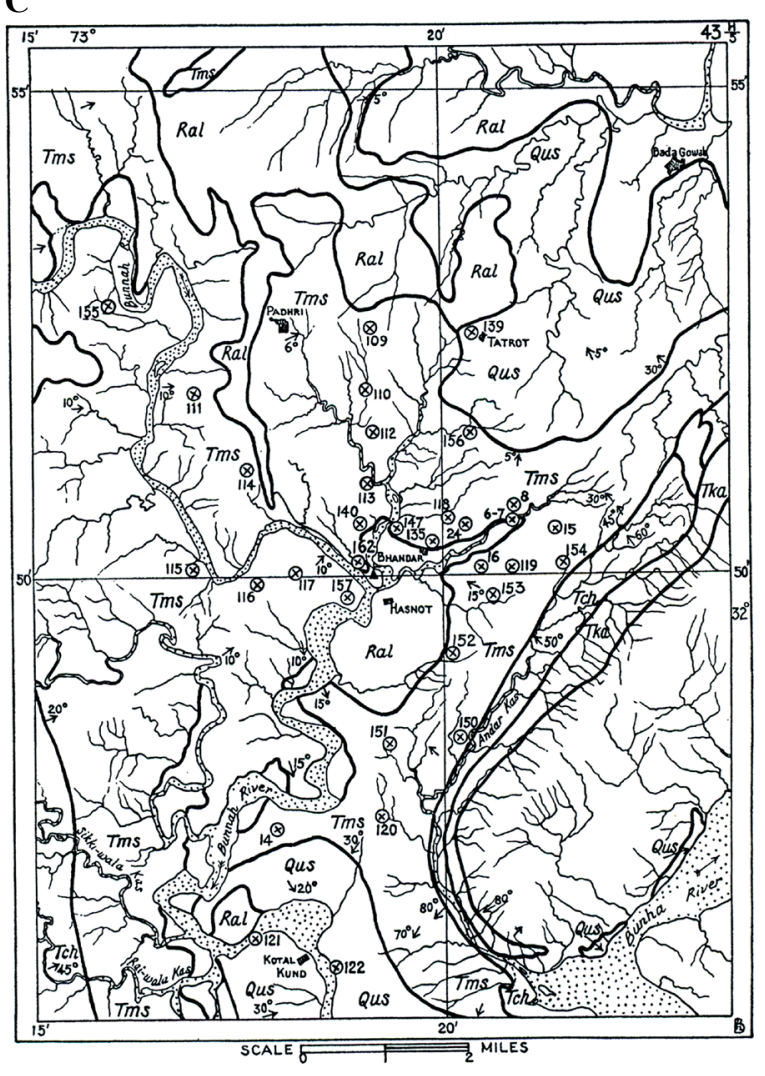

Figure 1. Dhok Pathan (A-B) and Hasnot (A,C) study areas (Colbert, 1935) showing the fossil localities from where the fossils of family Cervidae have been collected. The locality numbers are mentioned in the text. 
(1954), but C. colberti and Rucervus sp. I were synonymized with Rucervus simplicidens and Rucervus sp. II to Cervus elaphus by Croitor (2017). Cervus elaphus Linnaeus, 1758 was considered as generic type for Cervus sivalensis by Lydekker (1880) at the time of original description of this species from the Siwaliks. The following specimens available at Abu-Bakr Fossil Display and Research Centre have been examined to justify the Pliocene age based on the Cervidae fossils: PUPC $83 / 104$ (right mandibular fragment with $\mathrm{m} 1-2$, Figure 2A), PUPC 84/115 (left maxillary fragment with M2-3, Figure 2B), PUPC 87/276 (right mandibular fragment with broken

A
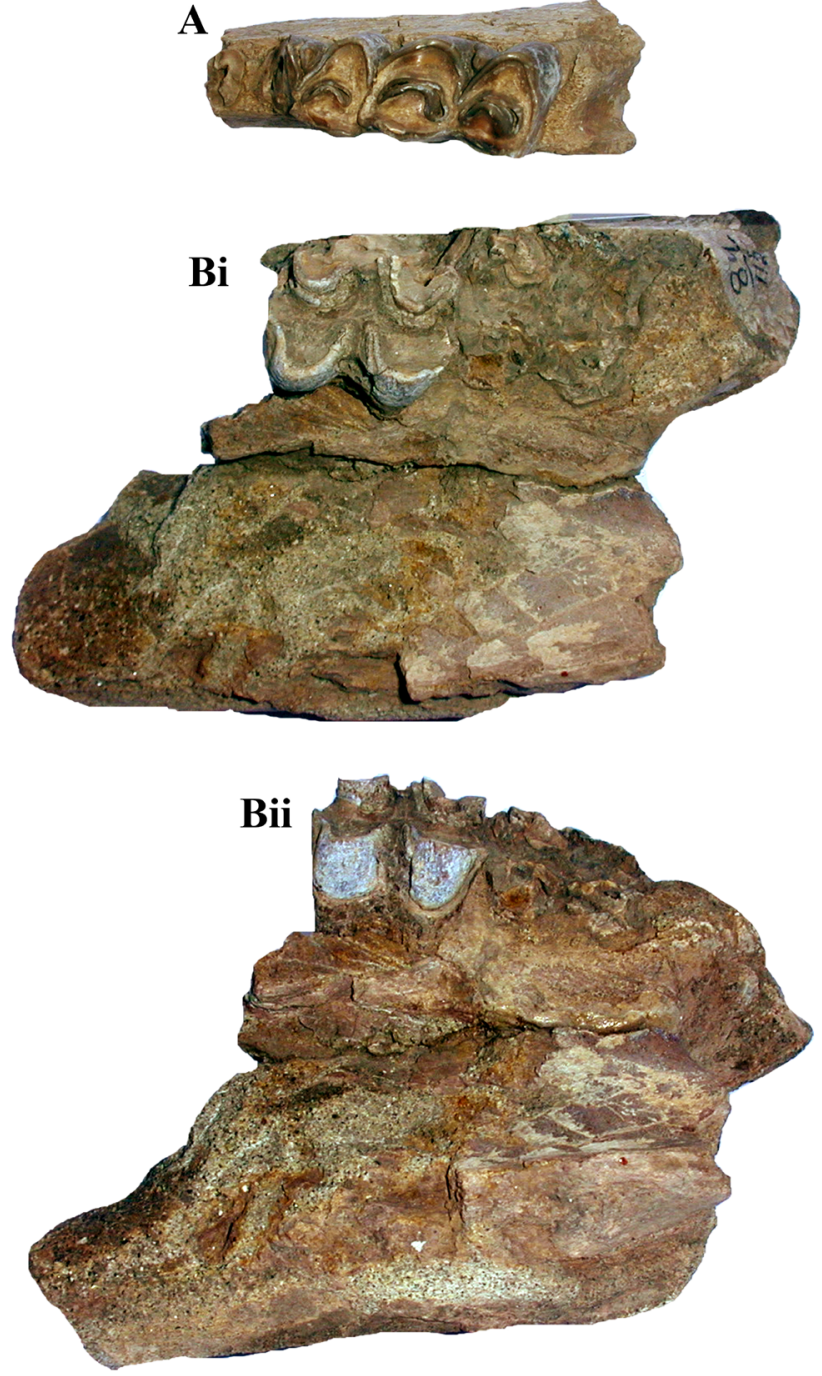

Gi
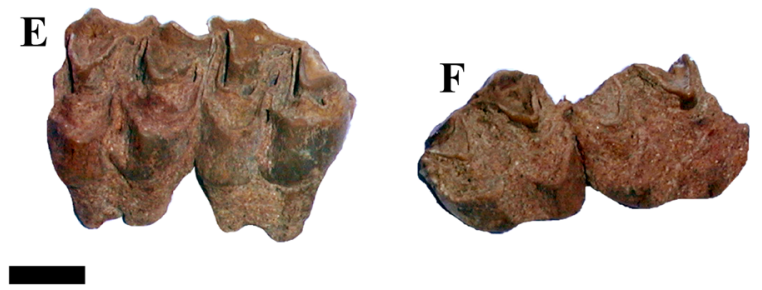

p2 and well preserved p3-m1, Figure 2C), PUPC 69/146 (left mandibular fragment with broken m1-3, Figure 2D), PUPC 98/77 (left and right maxillary fragments with M2-3, Figures $2 \mathrm{E}-\mathrm{F}$ ) and, left and right mandibular fragment with $\mathrm{m} 1-3$, Figure 2G); PUPC 83/119 (right mandibular fragment with m1-2 (Figure 3A), PUPC 87/279 left mandibular fragment with $m 2-3$, Figure 3B), PUPC 02/35 right mandibular fragment with m1-3 (Figure 3C), PUPC 05/12 (left mandibular fragment with $\mathrm{p} 2-\mathrm{m} 1$, Figure 3D); PUPC $83 / 105$ (right dentary fragment with $\mathrm{m} 2$ and roots of $\mathrm{m} 3$, Figure 4A), PUPC 85/96 (right dentary fragment with
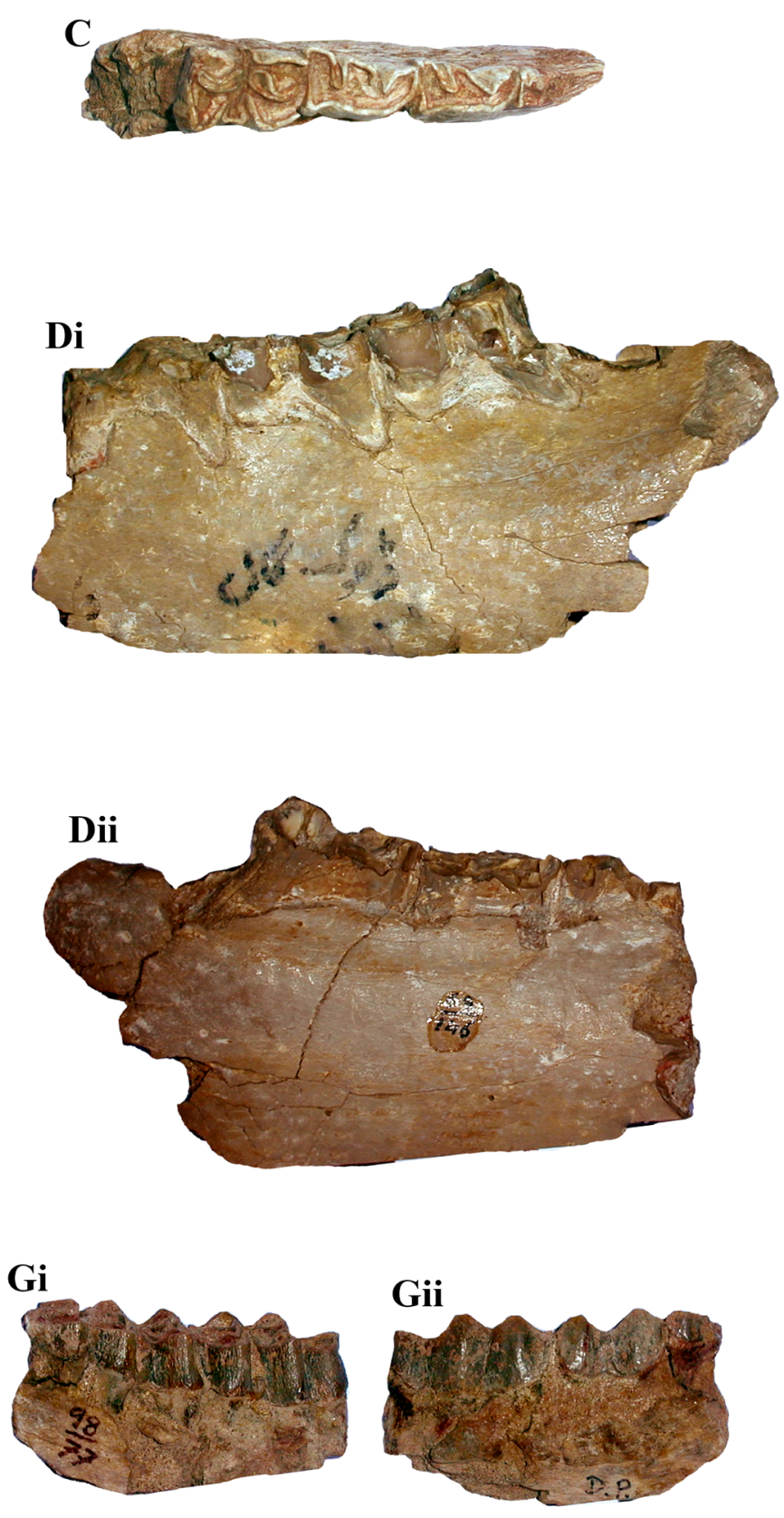

Figure 2. Rucervus simplicidens: PUPC 83/104, right mandibular fragment with m1-2; A, occlusal view. PUPC 84/115, left maxillary fragment with M2-3; Bi, occlusal view; Bii, lingual view. PUPC 87/276, right mandibular fragment with broken p2 and well-preserved p3-m1; C, occlusal view. Cervus triplidens: PUPC 69/146, left mandibular fragment with broken m1-3; Di, buccal view; Dii, lingual view. PUPC 98/77, left and right maxillary fragments with M2-3 and, left and right mandibular fragment with m1-3; E-F, occlusal view, Gi-Gii, lingual views. Scale bar $=10 \mathrm{~mm}$. 
p4-m3 and roots of p2-3 (Figure 4B), PUPC 01/34 (right dentary fragment with $\mathrm{m} 2-3$ (Figure $4 \mathrm{C}$ ), PUPC 02/1 (right dentary fragment with m2-3 (Figure 4D); PUPC 67/109 (left mandibular fragment with $\mathrm{m} 2-\mathrm{m} 3$, Figure 5A), PUPC 83/65 (left mandibular fragment with $\mathrm{p} 3-\mathrm{p} 4$ and $\mathrm{m} 2-\mathrm{m} 3$, Figure 5B), PUPC 83/643 (left mandibular fragment with p4-m1, Figure 5C), PUPC 85/97 (left mandibular fragment with $\mathrm{m} 2-\mathrm{m} 3$, Figure 5D), PUPC 10/30 (right mandibular fragment with $\mathrm{m} 1-\mathrm{m} 3$, Figure 5E).

Specimens PUPC 83/104, 84/115, 87/276, 67/109, 83/65, $83 / 643,85 / 97$ and 10/3 are referred to Rucervus simplicidens because the teeth are brachydont, molar crowns are square, slightly rugose enamel, median valley deep with less developed ectostylid and basal cingulum weak in these specimens when compared to Cervus triplidens and C. sivalensis. The specimens PUPC 69/146 and 98/77 are referred to C. triplidens as the teeth are hypsodont, the basal cingulum is slightly developed, median valley is deep, with fairly developed ectostylid and less rugose enamel, as compared to C. sivalensis. The specimens PUPC $84 / 119,87 / 279$ and 66/9 are referred to C. sivalensis because the hypsodont teeth, basal cingulum well developed, very rugose enamel and median valley deep with strong ectostylid when compared to $C$. triplidens. The specimens PUPC $02 / 35$, 05/12, 83/105, 85/95, 01/34 and 02/1 are referred to C. rewati due to their smaller size and brachydont teeth as compared to $C$. sivalensis. The strongly developed ectostylid slightly developed basal cingulum and the median valley is deep when compared to $R$. simplicidens. In Axis punjabiensis, the median valley is less deep when compared to $R$. simplicidens, and the ectostylid is absent. The comparison of these teeth with the holotype materials, the smaller size of teeth when compared to Giraffidae, and less rugose enamel and more prominent folding on the molars when compared to Bovidae, permit to associate these fossils with Cervidae. Moreover, the morphometric analyses, preservation of studied specimens, stage of wear, development of cones/conids and styles/stylids have already been described in detail in Ghaffar et al. (2004, 2010, 2011, 2015).

\section{DISCUSSION}

The paleontological work conducted in the Siwalik continental deposits particularly in the Dhok Pathan Formation (Middle Siwaliks) had many confusions and even doubts regarding the stratigraphic range of different

\section{Ai}
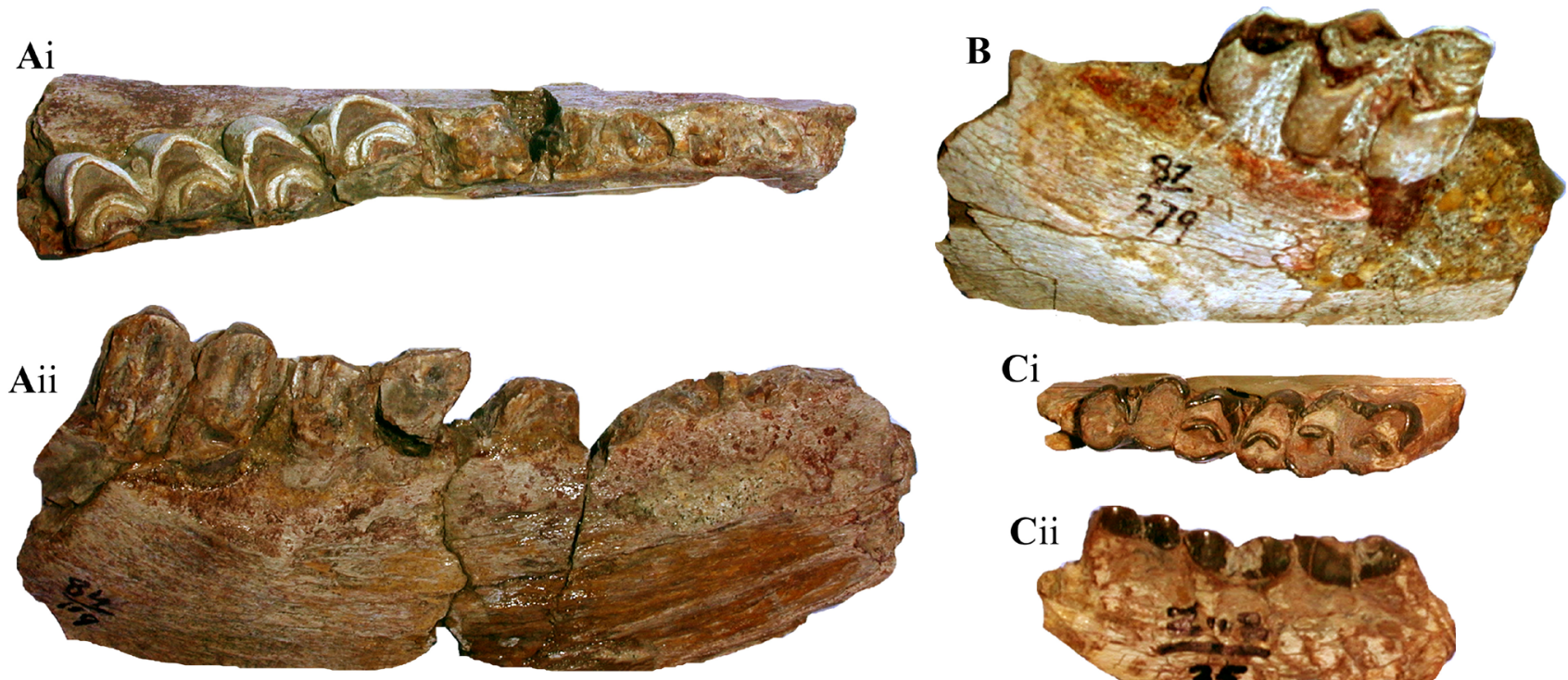

$\mathrm{Ci}$
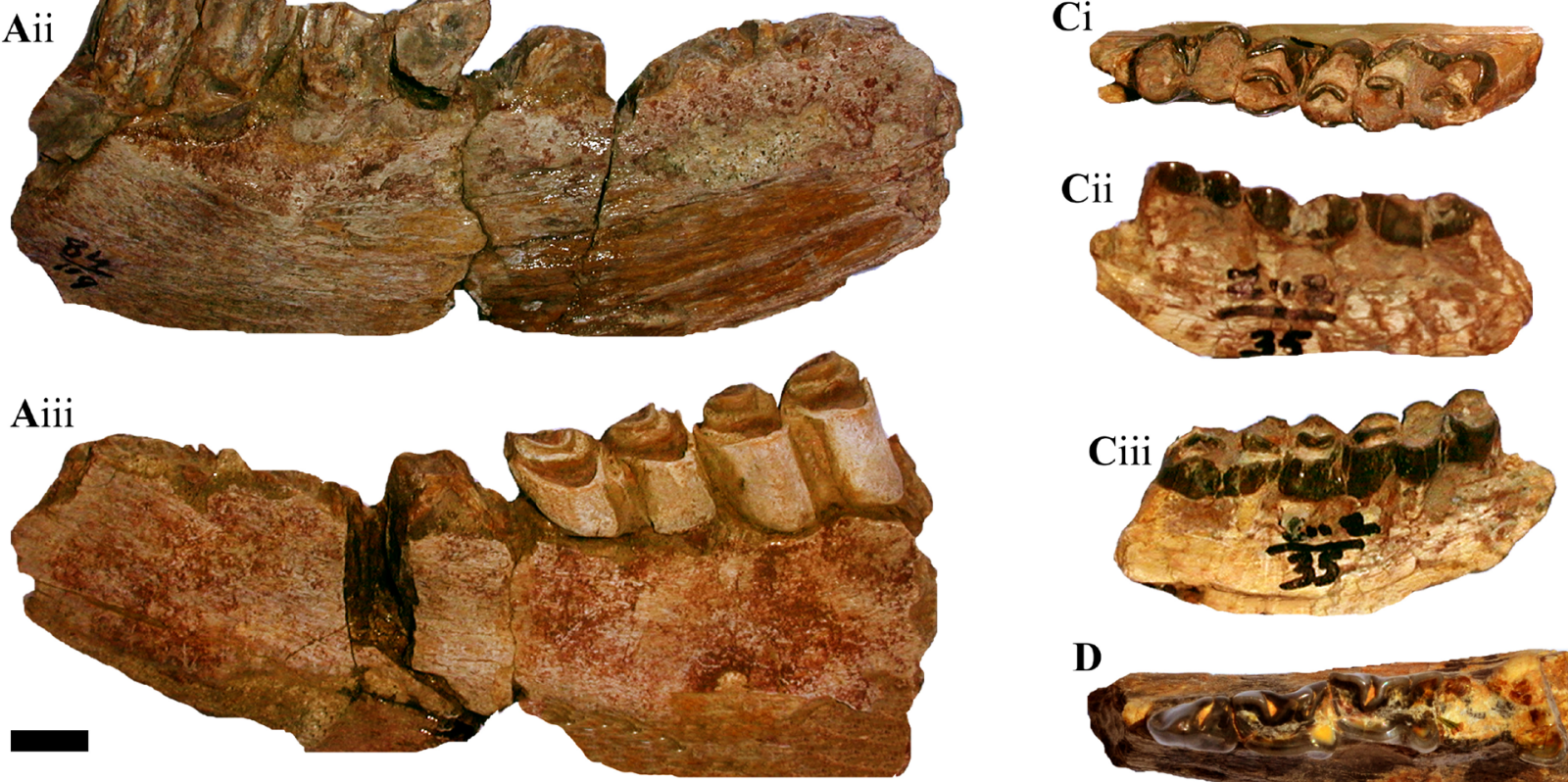

D

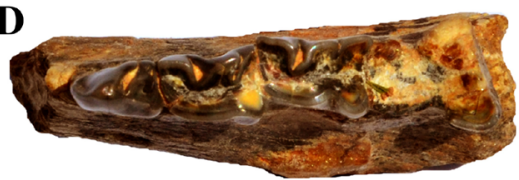

Figure 3. Cervus sivalensis: PUPC 84/119, left mandibular fragment with m2-3; Ai, occlusal view; Aii, lingual view; Aiii, buccal view. PUPC 87/279, right mandibular fragment with m3; B, buccal view. Cervus rewati: PUPC 02/35, right mandibular fragment with m1-3; Ci, occlusal view; Cii, lingual view; Ciii, buccal view. PUPC 05/12, left mandibular fragment with $\mathrm{p} 2-\mathrm{m} 1 ; \mathbf{D}$, occlusal view. Scale bar $=10 \mathrm{~mm}$. 

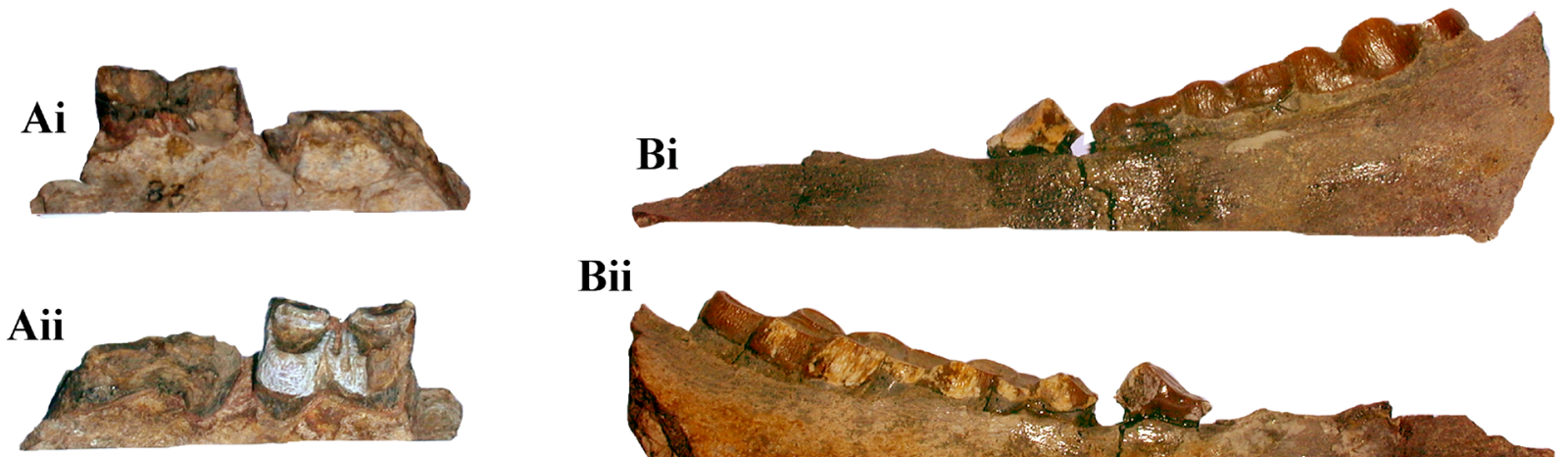

\section{Bii}

Aiii
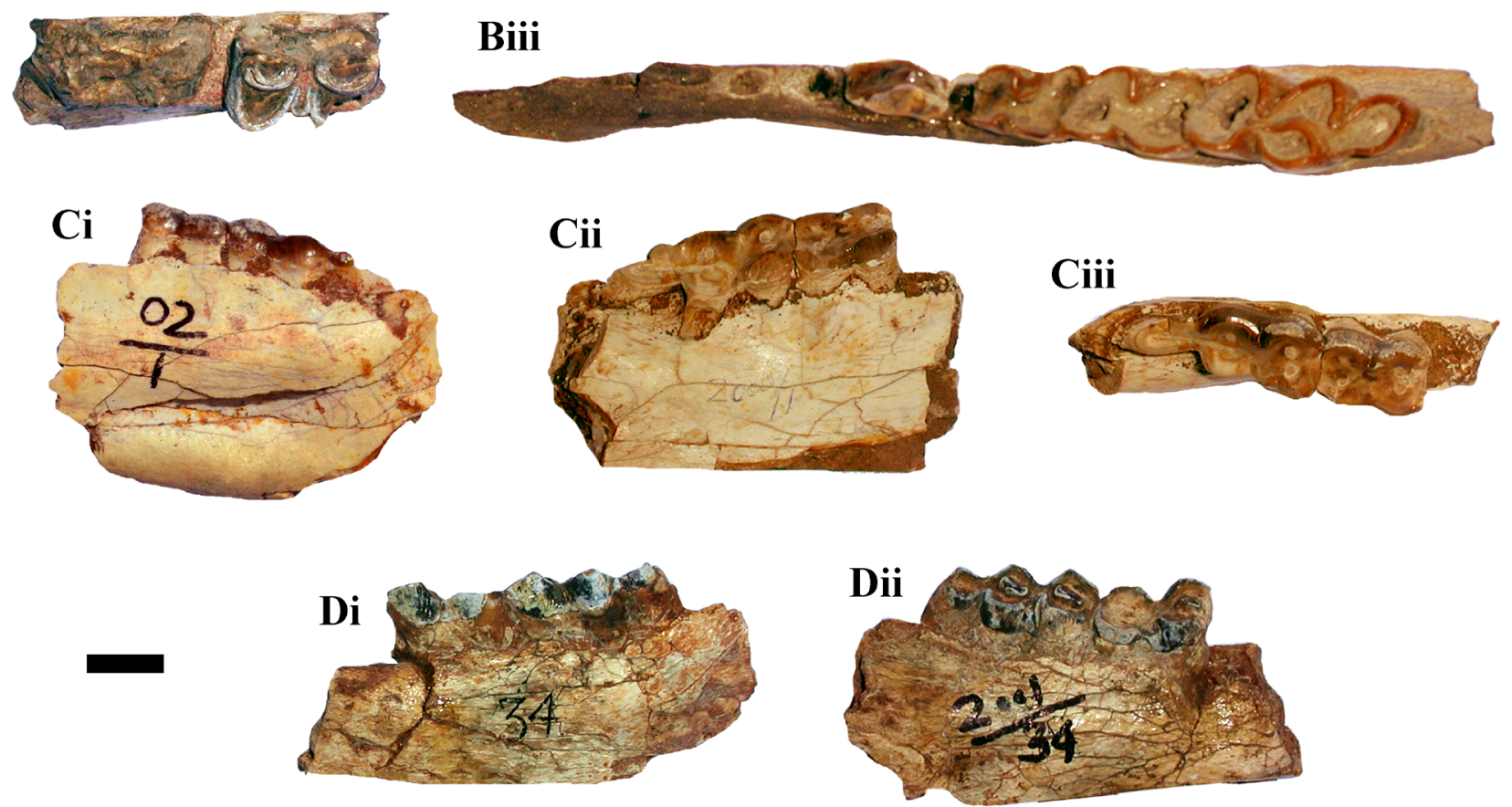

Figure 4. Cervus rewati: PUPC 83/105, Ai, lingual view; Aii, buccal view; Aiii, occlusal view. PUPC 85/96, Bi, lingual view; Bii, buccal view; Biii, occlusal view. PUPC 2001/34, Ci, lingual view; Cii, buccal view; Ciii, occlusal view. PUPC 2002/1, Di, occlusal view; Dii, buccal view. Scale bar = 10mm.
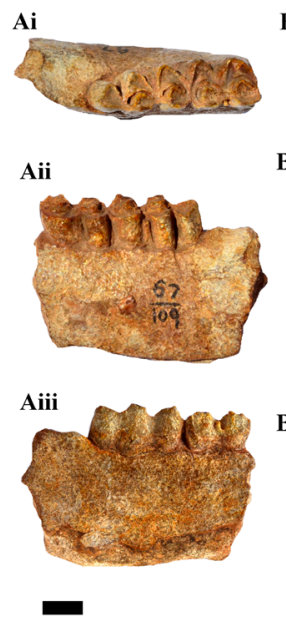

Bi

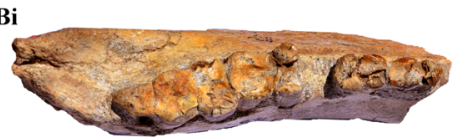

$\mathrm{Bii}$

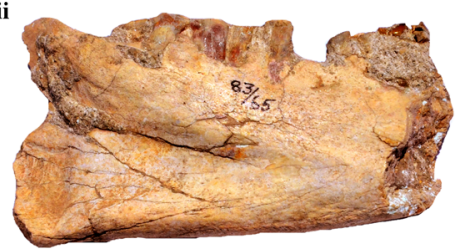

Biii
Ci
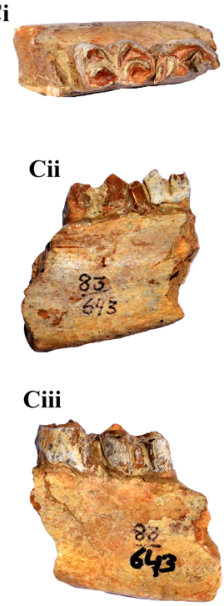
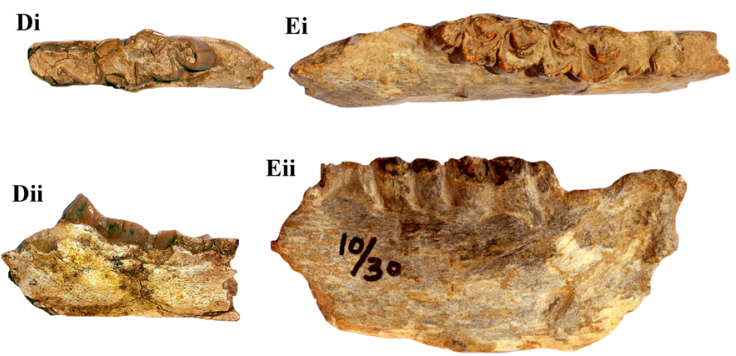

Diii
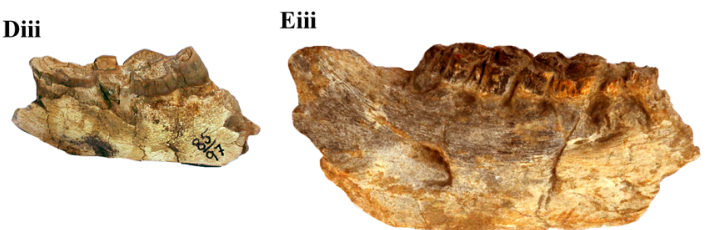

Figure 5. Rucervus simplicidens: PUPC 67/109, left mandibular fragment with m2-m3; Ai, occlusal view; Aii, buccal view; Aiii, lingual view. PUPC 83/65, left mandibular fragment with p3-p4 and m2-m3; Bi, occlusal view; Bii, buccal view; Biii, lingual view. PUPC 83/643, left mandibular fragment with p4-m1; Ci, occlusal view; Cii, buccal view; Ciii, lingual view. PUPC 85/97, left mandibular fragment with m2-m3; Di, occlusal view; Dii, buccal view; Diii, lingual view. PUPC 10/30, right mandibular fragment with m1-m3; Ei, occlusal view; Eii, buccal view; Eiii, lingual view. Scale bar $=10 \mathrm{~mm}$. 
species described so far. Barry et al. (2002) described the Siwalik fauna from the different fossil sites of Late Miocene (Dhok Pathan, Hasnot, Chinji and Khaur areas) in a very comprehensive way. For Dhok Pathan type section, Barry et al. (2002) argued that magnetozones are very short and their inconsistent rates give unrealistic estimates. Moreover, in this paper the Hasnot mammalian fauna is included without any detailed biostratigraphic context. Shah $(2009$, p. 296297) mentioned the age of the Dhok Patan Formation as early to middle Pliocene, and the Nagri Formation as early Pliocene, based on the mammalian fossil fauna listed. Shah (2009) included very few genera and species to his faunal list as compared to recent data published. The available fossil record from the Dhok Pathan Formation is much diversified than the mammalian fauna listed by Shah (2009). The fossil record available at Abu-Bakr Fossil Display and Research Centre (Khan et al., 2009, Ghaffar et al., 2010, 2011, 2015 and "unpublished data of Ghaffar and Khan") contain the fossil collections from Dhok Pathan and Hasnot, including the fossils of family Cervidae. The description of different species of the tribe Cervini (i.e. C. sivalensis, C. triplidens, C. rewati and $R$. simplicidens) are reported from the lower Pliocene and the molecular phylogenetic studies for the origin of these also agrees with this age (Ludt et al., 2004; Pitra et al., 2004; Ghaffar, 2005; Croitor \& Stefaniak, 2009; Ghaffar et al., 2010, 2011; Bibi \& Métais, 2016; Croitor, 2017). Although this description is based on the already described fossil record (Ghaffar et al., 2010, 2011, 2015), the generic attribution of some species is in progress with the discovery of new fossil materials, and assignment of these species to different genera (Axis, Cervus, and Rucervus) is still an open question. C. triplidensis is recognized by its medium size, high crowned cheek teeth with strong entostyle. Similarly, A. punjabiensis is also of medium size with rather high crowned cheek teeth and simple 3-point antlers. According to Croitor (2017), due to similar body size and hypsodont dentition, there is a possibility of synonymy between these two species. Moreover, high crowned cheek teeth and long posterior antler tine of distal bifurcation in $A$. punjabiensis represents a continuation of antler beam, unlike in modern Rusa unicolor. It does not allow assuming their direct ancestral relationship with sambar deer as described earlier (Azzaroli, 1954; Ghaffar et al., 2015). C. sivalensis is also a medium sized deer with a small lingual cingulum in molar teeth. According to Lydekker (1885), this species shows a close relationship with modern $R$. duvaucelii, and mentioned a cranium and antler fragments (AMNH 19829 and AMNH 19807) that show a certain resemblance to modern Rucervus. The antler is heavily built and its crown is formed by 3-crown tines inserted on the posterior side of the distal part of the beam as in modern $R$. duvaucelii. $C$. colberti Azzaroli (1954) is also similar to R. sivalensis in presence of weak cingulum in the upper molars. Azzaroli (1954) distinguished C. colberti from C. sivalensis by its more rounded protocone and hypocone (inner crests) and weaker cingulum. But according to Croitor (2017) the lingual outlines of inner cones depend of the stage of molar wear which appears very advanced in the type specimen (AMNH 19829), and therefore C. colberti is an advanced form closely related to $C$. sivalensis. Rucervus simplicidens differs from $C$. triplidens, $C$. sivalensis, $C$. colberti and $A$. punjabiensis by the absence of a cingulum in molars and more hypsodont teeth. Rucervus sp. I is characterized by a comparatively low position of the first tine, a very obtuse angle of the first ramification and a strong backward bending of the beam at the level of the first ramification, the occasional presence of accessory prongs above the first ramification and a small distal bifurcation (Azzaroli, 1954). Pitra et al. (2004) argued that the above-mentioned characteristics noticed by Azzaroli (1954) in this species correspond to modern Panolia eldi, which is a part of the C. elaphus evolutionary stock. According to Croitor (2017), characteristics noted by Azzaroli (1954) for Rucervus sp. II as a long cylindrical pedicle, high insertion of the first tine, and gentle curvature of the beam above the first bifurcation, most probably belong to $R$. simplicidens. $C$. rewati is the smallest cervid species equal in size to chital and fallow deer. According to Arif et al. (1991), the molar measurements of this species are close to those of modern chital A. axis, but Ghaffar et al. (2015) and Croitor (2017) mentioned that $C$. rewati differs from $A$. axis in having ectostylids and anterior enamel folds in the lower molars of this species. A more detailed description, taxonomy, stratigraphic related aspects, teeth dimensions, and comparison with holotypes of the above mentioned specimens can be found in Ghaffar (2005) and Ghaffar et al. (2010, 2011, 2015).

Based on the available Cervidae fossil record from the study areas (Dhok Pathan and Hasnot), as well as on the basiss of the literature review, it is observed that at the transition of Mio-Pliocene or most probably during the early Pliocene, giraffes were substituted by cervids and this substitution is very evident as an indicator of Pliocene age (Ghaffar et al., 2015). Another, important issue is that in these localities the fossil fauna is mostly found in pockets, and these pockets sometime yield the fauna of Chinji, Nagri and Dhok Pathan formations simultaneously. This phenomenon is more evident in the Hasnot area because in the Dhok Pathan type section, upper Miocene-Pliocene sediments are only exposed. During the terminal Miocene, open wooded grassland habitats replaced the earlier less seasonal woodland and forest habitats, and the environmental proxy data attest that such type of vegetation dominated in these localities (i.e. Dhok Pathan and Hasnot). From the late Miocene-early Pliocene, a gradual change occurred from a humid and warm climate to the drier and cooler conditions of the Pliocene. In the Siwaliks, this change led to a gradual replacement of evergreen tropical rainforest by deciduous forests and a vegetation mosaic. During the early Pliocene (i.e. $5 \mathrm{Ma}$ ) grasses dominated the vegetation with $\mathrm{C}_{3}$ trees and shrubs, and such condition would have favored the initial evolution of different cervid species since Indochina was mostly covered by rainforests and possibly by patches of deciduous forests (Shah, 1977; Quade et al., 1989; Heintz et al., 1990; Petronio et al., 2007, Badgley et al., 2008; Ghaffar et al., 2015; Croitor, 2017). In the Siwalik 
continental deposits, coarse-grained multistory thick sandstones bodies showing a scoured base, separated by a thin layer of mudstone is a characteristic of Pliocene sediments, and such features can be observed in the study areas (Dhok Pathan and Hasnot). Fossil remains of Pliocene artiodactyls are relatively abundant and attest the Pliocene age of these fossil localities. The prominent faunal elements of the studied fossil sites at Dhok Pathan and Hasnot area are Gazella, Pachyportax, Selenoportax, Tragoportax, Sivalhippus, Hydaspitherium, Giraffa, Dorcatherium, Propotamochoerus, Rhinoceros, Stegolohodon and Crocuta, in addition to different cervid species (Colbert, 1935; Ghaffar, 2005; Khan, 2007, 2009; Shah, 2009; Ghaffar et al., 2015; Bibi \& Métais, 2016). Therefore, the fossils of family Cervidae attest that there is a Pliocene exposure in these areas along with upper Miocene exposures. Earlier workers (Lydekker, 1876, 1880, 1882, 1884, 1886; Pilgrim, 1910, 1913, 1932, 1939; Matthew, 1929; Colbert, 1935) did not mention exact stratigraphic ranges, but later Barry et al. (2002) worked on the stratigraphic interval of 10.7-5.7 Ma in these areas. Pilgrim $(1910,1913)$ mentioned the age of Chinji and Nagri as Miocene, and Dhok Pathan as Pliocene. Colbert (1935) mentioned the age of Chinji, Nagri and Dhok Pathan as Pliocene. According to Barry et al. (2002), the age of Dhok Pathan and Hasnot area is late Miocene, while Shah (2009) mentioned the age of Chinji as late Miocene, Nagri as early Pliocene, and Dhok Pathan as early to middle Pliocene. According to the lithological characteristics and faunal assemblages, we think that to assign a Pliocene age to Chinji and Nagri is an exaggeration. On the other hand, to consider the Pliocene age to those fossil sites from where the Cervidae fossil remains have been recovered (Figure 1) is justified.

Dhok Pathan Formation has the transitional contact with the underlying Nagri Formation, while the upper contact of Dhok Pathan Formation is disconformable in the Potwar Province. Conglomerates in the form of lenses and a sandstone layer with a rich vertebrate fauna as compared to Lower Siwaliks and Upper Siwaliks is an essential characteristics of the upper Dhok Pathan Formation (Pliocene). At this stage, with very limited data of Cervidae remains, we can only argue that the previously described fossil localities of late Miocene age have also the Pliocene exposures along with the late Miocene exposures. In short, due to very high seismic activity and severe weathering effect, the role of ancient channels (Soan and Bunnah rivers) is very much different and even complicated to determine. Therefore, it is apparent that we must focus on the fossil finds along with lithological characteristics that show a diachronous nature of these sediments, and the fossil localities mentioned in this paper confirm this aspect.

\section{CONCLUSION}

From the Siwalik continental deposits, most of the exposures in Dhok Pathan and Hasnot areas had been recognized as upper Miocene. But the present study based on the Cervidae fossils, indicate that the fossil localities bearing these fossils are Pliocene and most of the sediments in the study area are diachronous.

\section{ACKNOWLEDGEMENTS}

The first author is grateful to M. Irfan Azeem for preparing the figures. All authors are thankful to R. Croitor and anonymous reviewer for their valuable comments and suggestions that improved the quality of the article. This research is supported by Higher Education Commission, Pakistan (grant no. 20-2234/R \& D/11) to A. Ghaffar under National Research Program for Universities (NRPU) to study Pliocene Mammalian Fauna from the Siwaliks of Pakistan.

\section{REFERENCES}

Akhtar, M. 1992. Taxonomy and distribution of the Siwalik bovids. University of the Punjab, Ph.D. thesis (unpublished), $372 \mathrm{p}$.

Arif, M.; Shah, S.M.I. \& De Vos, J. 1991. Cervus rewati sp. nov. (Mammalia, Cervidae) from the Upper Siwaliks of Pakistan. Quetta, Geological Survey of Pakistan, p. 11-24 (Memoirs 17).

Azanza, B.; Rössner, G.E. \& Ortiz-Jaureguizar, E. 2013. The early Turolian (late Miocene) Cervidae (Artiodactyla, Mammalia) from the fossil site of Dorn-Dürkheim 1 (Germany) and implications on the origin of crown cervids. Palaeobiodiversity and Palaeoenvironments, 93:217-258. doi:10.1007/s12549013-0118-8

Azzaroli, A. 1954. Critical observations upon Siwalik deer. Proceedings of the Linnean Society of London, 165:75-83. doi:10.1111/j.1095-8312.1954.tb00714.x

Badgley, C.; Barry, J.C.; Morgan, M.E.; Nelson, S.V.; Behrensmeyer, A.K.; Cerling, T.E. \& Pilbeam, D. 2008. Ecological changes in Miocene mammalian record show impact of prolonged climatic forcing. Proceeding of the National Academy of Sciences, 105:12145-12149. doi:10.1073/pnas.0805592105

Barry, J.C. \& Flynn, L.J. 1989. Key biostratigraphic events in the Siwalik Sequence. In: E.H. Lindsay; V. Fahlbusch \& P. Mein (eds.) European Neogene mammal chronology, Plenum Press, p. 557-571. doi:10.1007/978-1-4899-2513-8_33

Barry, J.C.; Morgan, M.; Flynn, L.J.; Pilbeam, D.; Behrensmeyer, A.K.; Raza, S.M.; Khan, I.; Badgely, C.; Hicks, J. \& Kelley, J. 2002. Faunal and environmental change in the Late Miocene Siwaliks of Northern Pakistan. Paleobiology, 28:1-71. doi:10.1666/0094-8373(2002)28[1:FAECIT]2.0.CO;2

Behrensmeyer, A.K.; Wills, B.J. \& Quade, J. 1995. Floodplains and paleosols of Pakistan Neogene and Wyoming Paleogene deposits: a comparative study. Palaeogeography, Palaeoclimatology, Palaeoecology, 115:37-60. doi:10.1016/0031-0182(94)00106-i

Bhatti, Z.H. 2004. Taxonomy, evolutionary history and biogeography of the Siwalik Giraffids. University of the Punjab, Ph.D. thesis (unpublished), $352 \mathrm{p}$.

Bibi, F. \& Métais, G. 2016. Evolutionary history of the large herbivores of South and Southeast Asia (Indomalayan Realm). In: F.S. Ahrestani \& M. Sankaran (eds.) The ecology of large herbivores in South and Southeast Asia, Dordrecht, Springer, p. 15-88 (Ecological Studies 225). doi:10.1007/978-94-017-7570-0_2

Brown, B. 1926. A new deer from the Siwalik. American Museum Novitates, 242:1-6.

Colbert, E.H. 1935. Siwalik mammals in the American Museum of Natural History. Transactions of the American Philosophical Society, 26:1-401. doi:10.2307/1005467

Croitor, R. 2014. Deer from Late Miocene to Pleistocene of Western Palearctic: matching fossil record and molecular phylogeny data. Zitteliana, B32:115-153. 
Croitor, R. 2017. Description of a new deer species (Cervidae, Mammalia) from the Early Pliocene of Eastern Europe, with a review of early dispersal and paleobiogeography of the subfamily Cervinae. Neues Jahrbuch für Geologie und Paläontologie Abhandlungen, 283:85-108. doi.10.1127/njgpa/2017/0630

Croitor, R. \& Stefaniak, K. 2009. Early Pliocene deer of Central and Eastern European regions and inferred phylogenetic relationships. Palaeontographica Abteilung A, 287:1-39. doi:10.1127/pala/287/2009/1

Di Stefano, G. \& Petronio, C. 2002. Systematics and evolution of the Eurasian Plio-Pleistocene tribe Cervini (Artiodactyla, Mammalia). Geologica Romana, 36:311-334.

Falconer, H. \& Cautley, P.T. 1849. Equidae, Camelidae and Sivatherium. Fauna Antiqua Sivalensis, Part-9. London, Smith, Elder \& Co., 139 p.

Farooq, U. 2006. Studies of evolutionary trends in dentition of the Siwalik tragulids. University of the Punjab, Ph.D. thesis (unpublished), $340 \mathrm{p}$.

Ghaffar, A. 2005. Studies on equids, cervids and Carnivora from the Siwalik Hills of Pakistan. University of the Punjab, Ph.D. thesis (unpublished), $389 \mathrm{p}$.

Ghaffar, A.; Khan, M.A. \& Akhtar, M. 2010. Early Pliocene Cervids (Artiodactyla, Mammalia) from the Siwaliks of Pakistan. Yerbilimleri (Earth Sciences), 31, 217-231.

Ghaffar, A.; Akhtar, M.; Khan, M.A. \& Nazir, M. 2004. Report on Cervus sivalensis from the Upper Siwaliks of Pakistan. Punjab University Journal of Zoology, 19:83-88.

Ghaffar, A.; Khan, M.A. \& Akhtar, M. 2010. Early Pliocene Cervids (Artiodactyla, Mammalia) from the Siwaliks of Pakistan. Yerbilimleri (Earth Sciences), 31, 217-231.

Ghaffar, A.; Akhtar, M.; Khan, M.A.; Samiullah, K. \& Khan, A.M. 2011. Cervus cf. rewati (Cervidae) from Dhok Pathan Formation (Middle Siwaliks), Pakistan. Austrian Journal of Earth Sciences, 104:107-113.

Ghaffar, A.; Akhtar, M.; Khan, M.A. \& Siddiq, M.K. 2015. New fossil remains of family Cervidae from Dhok Pathan Formation (Middle Siwaliks) of Pakistan. Geosciences Journal, 19:631639. doi:10.1007/s12303-015-0001-x

Heintz, É.; Brunet, M.; Battail, B. \& Jehenne, Y. 1990. The main features of the Cervid palaeobiogeography. Quartärpaläontologie, 8:79-82.

Khan, M.A. 2007. Taxonomic studies on fossil remains of ruminants from tertiary Hills of Hasnot, Pakistan. University of the Punjab, $\mathrm{Ph} . \mathrm{D}$. thesis (unpublished), $292 \mathrm{p}$.

Khan, A.M. 2009. Taxonomy and distribution of rhinoceroses from the Siwalik Hills of Pakistan. University of the Punjab, Ph.D. thesis (unpublished), $182 \mathrm{p}$.

Khan, M.A.; Iliopoulos, G. \& Akhtar, M. 2009. Boselaphines (Artiodactyla, Ruminantia, Bovidae) from the Middle Siwaliks of Hasnot, Pakistan. Geobios, 42:739-753. doi:10.1016/j. geobios.2009.04.003

Ludt, J.C.; Schroeder, W.; Rottman, O. \& Kuehn, R. 2004. Mitochondrial DNA phylogeograph of red deer (Cervus elaphus). Molecular Phylogenetics and Evolution, 31:10641083. doi:10.1016/j.ympev.2003.10.003

Lydekker, R. 1876. Molar teeth and other remains of Mammalia from the Indian Tertiaries. Paleontologica Indica, 1:19-87.

Lydekker, R. 1880. Indian Tertiary and post-Tertiary Vertebrata. Palaeontologia Indica, 1:182-294

Lydekker, R. 1882. Siwalik and Narbada Equidae. Paleontologica Indica, 2:67-98.
Lydekker, R. 1884. Rodents and New Ruminants from the Siwalik and synopsis of Mammalia. Palaeontologia Indica, 3:105-134.

Lydekker, R. 1885. Catalogue of the remains of Siwalik Vertebrata contained in the geological department of the Indian Museum. Calcutta, Indian Museum, Part 1, 116 p.

Lydekker, R. 1886. Indian Tertiary vertebrate: Siwaliks. Mammalia. Supplement I. Paleontologica Indica, 4:1-22.

Matthew, W.D. 1929. Critical observations upon Siwalik Mammals. New York, American Museum of Natural History, p. 437-560 (Bulletin 56).

Petronio, C.; Krakhmalnaya, T.; Bellucci, L. \& Di Stefano, G. 2007. Remarks on some Eurasian pliocervines: characteristics, evolution, and relationships with the tribe Cervini. Geobios, 40:113-130. doi:10.1016/j.geobios.2006.01.002

Pilgrim, G.E. 1910. Notices of new Mammalian genera and species from the Tertiaries of India-Calcutta. Kolkata, The Geological Survey of India, p. 63-71. (Records 40).

Pilgrim, G.E. 1913. Correlation of the Siwaliks with mammal horizons of Europe. Kolkata, The Geological Survey of India, p. 264-326. (Records 43).

Pilgrim, G.E. 1932. The fossil Carnivora of India. Kolkata, The Geological Survey of India, 232 p. (Memoirs 18).

Pilgrim, G.E. 1937. Siwalik antelopes and oxen in the American Museum of Natural History. New York, American Museum of Natural History, p. 729-874 (Bulletin 72).

Pilgrim, G.E. 1939. The fossil Bovidae of India. Paleontologica Indica, 26:1-356.

Pitra, C.; Fickela, J.; Meijaard, E. \& Groves, C.P. 2004. Evolution and phylogeny of old world deer. Molecular Phylogenetics and Evolution, 33:880-895. doi:10.1016/j.ympev.2004.07.013

Quade, J.; Cerling, T.E. \& Bowman, J.R. 1989. Development of Asian monsoon revealed by marked ecological shift during the latest Miocene in northern Pakistan. Nature, 402:163-166. doi: $10.1038 / 342163 a 0$

Sarwar, M. 1977. Taxonomy and distribution of the Siwalik Proboscidea. Punjab, Department Zoology, University of Punjab, 172 p. (Bulletin 10).

Shah, S.M.I. 1977. Stratigraphy of Pakistan. Quetta, Geological Survey of Pakistan, 138 p. (Memoirs 12).

Shah, S.M.I. 2009. Stratigraphy of Pakistan. Quetta, Geological Survey of Pakistan, 381 p. (Memoirs 22).

Wang, L.-H. \& Zhang, Z.-Q. 2014. Late Miocene Cervavitus novorossiae (Cervidae, Artiodactyla) from Lantian, Shaanxi Province. Vertebrata PalAsiatica, 7:303-315.

Wills, B. \& Behrensmeyer, A.K. 1995. Fluvial systems in the Siwalik Neogene and Wyoming Paleogene. Palaeogeography, Palaeoclimatology, Palaeoecology, 114:13-35. doi:10.1016/0031-0182(94)00105-h

Received in 02 April, 2017; Accepted in 15 January, 2018. 